\title{
EFEK LAMA PENYIMPANAN SEMEN BEKU SAPI BALI PADA POS INSEMINASI BUATAN TERHADAP MEMBRAN PLASMA, TUDUNG AKROSOM UTUH, DAN DNA SPERMATOZOA
}

\section{The Storage Duration Effects of Bali Bull's Frozen Semen at Artificial Insemination Station on Plasma Membrane Integrity, Acrosome Integrity, and Spermatozoa DNA}

\author{
Fikri Ardhani ${ }^{1}$, Hayatul Mufidah', Rahmah Samsuriati' ${ }^{1}$, dan Hilman Pratama Putra ${ }^{1}$ \\ 1Jurusan Peternakan, Fakultas Pertanian, Universitas Mulwarman \\ Email: fikri_ardhani@faperta.unmul.ac.id
}

\begin{abstract}
INTISARI
Tujuan penelitian ini adalah untuk mengetahui pengaruh lama penyimpanan semen beku Sapi Bali di pos inseminasi buatan Kota Samarinda, Kalimatan Timur terhadap kualitas motilitas, viabilitas, velositas, abnormalitas, membran plasma utuh (MPU), tudung akrosom utuh (TAU), dan kerusakan DNA spermatozoa. Rancangan penelitian menggunakan rancangan acak lengkap (RAL) dengan 5 perlakuan (lama penyimpanan) dan 5 kali ulangan. Semen beku Sapi Bali yang digunakan hasil produksi tahun 2009 (lama penyimpanan 10 tahun), 2011 (lama penyimpanan 7 tahun), 2013 (lama penyimpanan 5 tahun), 2015 (lama penyimpanan 3 tahun), dan 2017 (lama penyimpanan 1 tahun). Lama penyimpanan semen beku yang disimpan selama satu sampai sepuluh tahun pada nitrogen cair di pos inseminasi buatan Kota Samarinda, Kalimatan Timur masih layak digunakan untuk inseminasi buatan berdasarkan kualitas motilitas $(44,99 \pm 2,40 \%)$, viabilitas $(55,33 \pm 2,60 \%)$, velositas $(0,050 \pm 0,002 \mathrm{~mm} /$ detik), abnormalitas $(12,87 \pm 1,09 \%)$, membran plasma utuh $(58,83 \pm 1,86 \%)$, tudung akrosom utuh $(75,48 \pm 1,61 \%)$, dan kerusakan DNA spermatozoa $(1,60 \pm 0,21 \%)$.
\end{abstract}

Kata kunci: DNA, Lama Penyimpanan, Membran Plasma Utuh, Semen Beku, Tudung Akrosom Utuh

\begin{abstract}
The purpose of this study was to determine the effect of frozen storage time for Bali Bull in artificial insemination station in Samarinda City, East Kalimantan on the quality of motility, viability, velocity, abnormality, plasma membrane integrity (MIn), acrosome integrity (AIn), and DNA damage of spermatozoa. The study design used a completely randomized design (CRD) with 5 treatments (storage time) and 5 replications. Frozen semen of Bali Bull used in 2009 (10 years of storage), 2011 (7 years of storage), 2013 (5 years of storage), 2015 (3 years of storage), and 2017 (1 year of storage). The storage time of frozen semen stored for one to ten years in liquid nitrogen at the artificial insemination station in Kota Samarinda, East Kalimantan was still suitable for use in artificial insemination based on motility quality (44.99 $\pm 2.40 \%)$, viability $(55.33 \pm 2,60 \%)$, velocity $(0.050 \pm 0.002 \mathrm{~mm} / \mathrm{sec})$, abnormality (12.87 $\pm 1.09 \%)$, plasma membrane integrity (58.83 \pm $1.86 \%)$, acrosome integrity (75.48 $\pm 1,61 \%)$, and DNA damage of spermatozoa (1.60 $\pm 0.21 \%)$.
\end{abstract}

Keywords: DNA, Storage Duration, Plasma Membrane Integrity, Frozen Semen, Acrosome Integrity

\section{PENDAHULUAN}

Inseminasi buatan (IB) merupakan salah satu bentuk penerapan teknologi reproduksi dalam rangka perbaikan mutu genetik dan upaya peningkatan populasi secara efisien. Tujuan tersebut agar dapat tercapai harus didukung oleh kualitas semen yang baik, sebab keberhasilan IB ditentukan oleh kualitas semen beku, faktor kesuburan betina, dan keterampilan inseminator. Faktorfaktor seperti koleksi semen, proses pembekuan hingga proses penyimpanan semen dapat menurunkan motilitas, keutuhan membran plasma, keutuhan tudung akrosom, dan merusak DNA spermatozoa. Spermatozoa yang memiliki morfologi normal, kromatin utuh, serta memiliki viabilitas dan motilitas 
yang baik adalah spermatozoa yang memiliki kemampuan fertilitas tinggi (Syauqy, 2014).

Jenis produsen semen beku dan permintaan peternak yang beragam, seringkali menyebabkan pos inseminasi buatan melakukan pengadaan stok semen beku dalam jumlah yang tidak sedikit. Semen beku yang paling banyak distok oleh pos inseminasi buatan di Kalimantan Timur adalah jenis Sapi Bali, dikarenakan populasi jenis sapi ini sangat dominan. Semen beku tersebut disimpan dalam kontainer berisi nitrogen cair dengan suhu $-196^{\circ} \mathrm{C}$ (Fauzan et al., 2014). Stok semen beku produksi 10 tahun terakhir seringkali dijumpai pada pos inseminasi buatan. Pengujian kualitas semen beku dianggap penting dilakukan dengan lama penyimpanan yang berbeda pada setiap pos inseminasi buatan.

Pengamatan kualitas semen beku ini pada dasarnya adalah untuk menjamin spermatozoa yang akan digunakan masih dalam kategori superior, sebab untuk dapat melakukan fertilisasi, spermatozoa dari semen beku harus hidup, motil, mempunyai morfologi, dan keutuhan DNA yang baik. Tujuan penelitian ini adalah untuk mengetahui pengaruh lama penyimpanan semen beku Sapi Bali pada setiap pos inseminasi buatan terhadap motilitas, viabilitas, velositas, abnormalitas, membran plasma utuh (MPU), tudung akrosom utuh (TAU), dan kerusakan DNA spermatozoa.

\section{MATERI DAN METODE}

Penelitian ini dilaksanakan di Laboratorium Reproduksi dan Pemuliaan Ternak, Jurusan Peternakan, Fakultas Pertanian, Universitas Mulawarman pada bulan Juli sampai Desember 2018.

\section{Materi Penelitian}

Bahan yang digunakan pada penelitian adalah semen beku Sapi Bali dengan tahun produksi 2009 (10 tahun), 2011 (7 tahun), 2013 (5 tahun), 2015 (3 tahun), dan 2017 (1 tahun) yang tersedia di pos inseminasi buatan Kota Samarinda. Semen beku tersebut disimpan dalam kontainer berisi nitrogren cair dengan suhu $-196^{\circ} \mathrm{C}$. Bahan lain yang digunakan antara lain air hangat, aquades, eosin-nigrosin, larutan hypoosmotic swelling test (HOSTest), toluidine blue, etanol 96\%, aseton, $\mathrm{HCl}$, t-butanol, dan xylol. Alat yang digunakan yaitu mikroskop cahaya, mikropipet, object glass, cover glass, heating table, tabung eppendorf, gunting, alat tulis, dan kamera.

\section{Metode Penelitian}

Metode thawing yang digunakan menurut Kusumawati et al. (2016) yaitu pada suhu thawing $37^{\circ} \mathrm{C}$ dan lama thawing 30 detik. Rancangan penelitian yang digunakan adalah rancangan acak lengkap (RAL) dengan 5 perlakuan (lama penyimpanan) dan 5 kali ulangan. Peubah yang diamati pada penelitian ini adalah motilitas, viabilitas, velositas, abnormalitas, membran plasma utuh (MPU), tudung akrosom utuh (TAU), dan kerusakan DNA spermatozoa.

\section{Analisis data}

Data hasil penelitian yang diperoleh dianalisis menggunakan sidik ragam dan untuk melihat perbedaan antar perlakuan dilakukan uji lanjut Duncan's Multiple Range Test (DMRT).

\section{HASIL DAN PEMBAHASAN}

\section{Motilitas}

Motilitas spermatozoa adalah jumlah sel spermatozoa yang hidup dan bergerak maju atau progresif. Pergerakan spermatozoa bergantung pada fungsi mitokondria. Kerusakan mitokondria berkaitan dengan perubahan suhu yang dapat menurunkan kemampuan bergerak spermatozoa (Sukmawati et al., 2014).

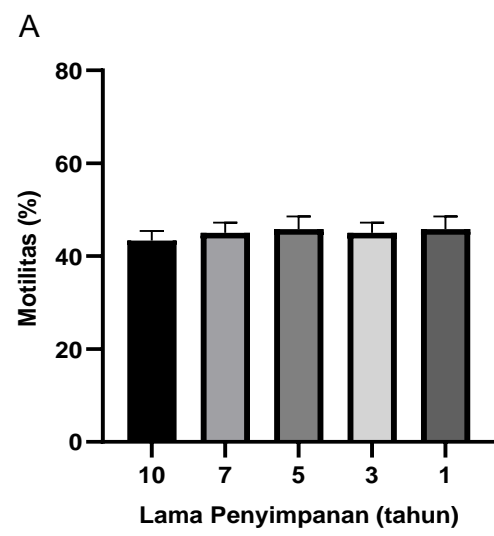

Gambar 1. Persentase motilitas spermatozoa semen beku. 
Data hasil penelitian menunjukkan bahwa nilai rata-rata motilitas spermatozoa yang disimpan selama satu sampai dengan sepuluh tahun yaitu 44,99 $\pm 2,40 \%$ (Gambar 1 ), artinya bahwa semen beku ini masih layak digunakan untuk inseminasi buatan. Motilitas spermatozoa setelah thawing minimal $40 \%$ jika kurang dari 40\% maka semen beku tersebut tidak layak diinseminasikan (Feradis, 2010). Selanjutnya berdasarkan hasil pengujian statisik diketahui bahwa lama penyimpanan yang berbeda menunjukkan pengaruh tidak nyata $(P>0,05)$ terhadap motilitas spermatozoa Sapi Bali. Hasil tersebut menunjukkan bahwa kualitas semen Sapi Bali yang disimpan, masih sesuai dengan persyaratan SNI (2008) bahwa semen beku sesudah dicairkan kembali (post thawing) pada suhu $37^{\circ} \mathrm{C}$ selama 30 detik harus menunjukkan motilitas minimal $40 \%$ dan derajat gerak individu spermatozoa minimal 2 (dua).

\section{Viabilitas}

Viabilitas spermatozoa (viable sperm) adalah salah satu indikator untuk menguji spermatozoa yang hidup dengan membran yang masih utuh. Viabilitas spermatozoa biasanya dinilai dengan memeriksa motilitas dan rasio hidup atau mati. Ketahanan hidup spermatozoa sangat berpengaruh terhadap keberhasilan IB ataupun proses fertilisasi di dalam organ reproduksi betina (Sukmawati et al, 2014).

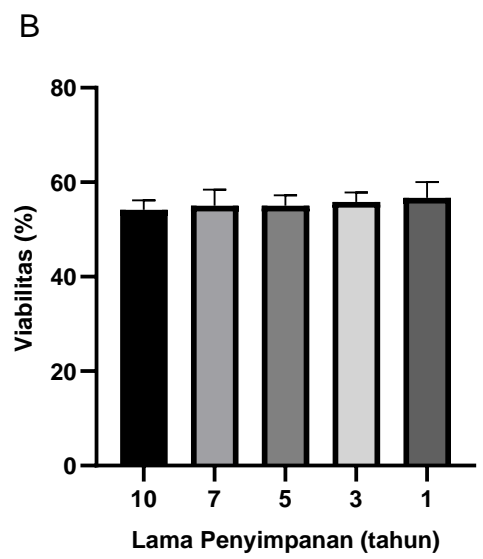

Gambar 2. Persentase spermatozoa hidup.

Viabilitas spermatozoa Sapi Bali dapat dilihat pada Gambar 2. Berdasarkan hasil pengujian statistik didapatkan bahwa lama penyimpanan semen beku yang berbeda tidak berpengaruh nyata $(\mathrm{P}>0,05)$ terhadap viabilitas spermatozoa Sapi Bali. Rata-rata viabilitas spermatoazoa dari semen beku yang disimpan di bawah 10 tahun pada setiap pos inseminasi buatan adalah 55,33 $\pm 2,60 \%$. Hal ini menunjukan bahwa semen beku masih dapat digunakan, sebab untuk dapat dilakukan inseminasi setidaknya diperlukan $50 \%$ spermatozoa yang hidup dan motil.

Sekitar 30\% spermatozoa akan mati selama pembekuan dan yang bertahan hidup sangat sensitif terhadap lingkungnan serta mempunyai daya hidup yang pendek setelah thawing (Situmorang et al., 2000). Daya hidup spermatozoa selama pembekuan akan baik dengan tetap terjaganya membran plasma sehingga proses metabolisme di dalam spermatozoa akan berjalan dengan baik. Metode thawing juga mempengaruhi persentase viabilitas spermatozoa. Metode thawing yang digunakan dalam penelitian ini merujuk hasil penelitian Kusumawati et al. (2016) menggunakan suhu $37^{\circ} \mathrm{C}$ selama 30 detik yang memberikan tingkat viabilitas tertinggi jika dibanding metode lainnya.

Viabilitas yang tinggi terkait dengan proses metabolisme dan aktivitas seluler spermatozoa yang berjalan optimal setelah proses thawing. Inkubasi semen pada suhu $37^{\circ} \mathrm{C}$ sangat dianjurkan karena mendekati suhu tubuh hewan dan sesuai dengan lingkungan in vivo sehingga memberikan daya hidup yang lebih baik. Pada suhu fisiologis $\left(37^{\circ} \mathrm{C}\right)$ membran plasma lebih permeable daripada suhu yang lebih rendah. Kerusakan membran plasma selama proses pembekuan dan thawing disebabkan karena terjadinya peroksidasi lipid pada spermatozoa yang disimpan lama yang dapat menurunkan daya hidup dan mempengaruhi pengawetan semen untuk inseminasi buatan (Toelihere, 1993).

\section{Velositas}

Kecepatan gerak maju spermatozoa dalam setiap ejakulat semen memiliki variasi kecepatan yang berbeda-beda. Davila et al. (2015) menyebutkan bahwa berdasarkan kecepatan spermatozoa umumnya dibagi menjadi 3 kategori yaitu lambat $(0,010$ $\mathrm{mm} /$ detik), sedang $(0,010-0,050 \mathrm{~mm} /$ detik $)$, dan cepat $(0,050 \mathrm{~mm} /$ detik $)$. Spermatozoa dikategorikan immotile jika velositasnya di bawah 0,010 mm/detik. Kecepatan spermatozoa dalam bergerak dibutuhkan 
dalam menjangkau ovum untuk melakukan proses fertilisasi.

Spermatozoa yang bergerak cepat memungkinkan penetrasi lebih cepat terjadi, sehingga tingkat keberhasilan fertilisasi semakin meningkat. Sebaliknya spermatozoa yang bergerak lambat membutuhkan waktu yang cukup lama untuk dapat menjangkau ovum di dalam saluran reproduksi betina. Semakin lama proses fertilisasi terjadi dapat menurunkan motilitas dan viabilitas spermatozoa di dalam saluran reproduksi betina.

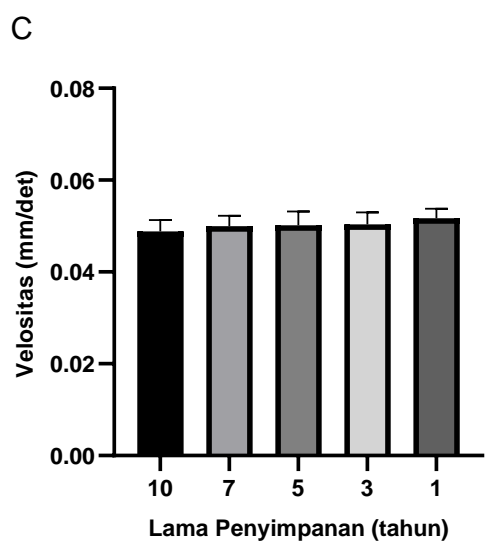

Gambar 3. Velositas spermatozoa dalam $\mathrm{mm} /$ detik.

Hasil pengujian statistik menunjukkan bahwa lama penyimpanan semen yang berbeda tidak berpengaruh nyata $(\mathrm{P}>0,05)$ terhadap velositas spermatozoa Sapi Bali (Gambar 3). Rata-rata velositas spermatozoa Sapi Bali yang disimpan pada nitrogen cair pada setiap pos inseminasi buatan yaitu 0,050 $\pm 0,002 \mathrm{~mm} /$ detik (kategori cepat). Faktor penyimpanan di bawah titik beku $\left(-196^{\circ} \mathrm{C}\right)$ sangat berpengaruh terhadap aktifitas maupun gerakan spermatozoa sebagai akibat dari proses metabolisme dan penurunan $\mathrm{pH}$, ketersediaan energi dalam bahan pengencer makin berkurang, semakin menuanya umur spermatozoa berupa melemahnya gerakan spermatozoa, di samping faktor viskositas (kepekatan) medium (Ichwandi, 2004).

\section{Abnormalitas}

Abnormalitas spermatozoa merupakan kelainan fisik dari spermatozoa yang terjadi karena pada saat proses pembentukan spermatozoa dalam tubuli seminiferi (abnormalitas primer) maupun karena proses perjalanan spermatozoa melalui saluransaluran organ kelamin jantan (abnormalitas sekunder). Abnormalitas juga dapat disebabkan preparasi yang kurang tepat (Arsiwan et al., 2014).

Nilai abnormalitas yang tinggi dapat pula disebabkan oleh pemindahan kontainer yang berulang-ulang pada proses distribusi. Pemindahan tersebut mengakibatkan terjadinya pemaparan suhu yang ekstrim, dimana disimpan pada suhu yang rendah $\left(-196^{\circ} \mathrm{C}\right)$ ke suhu lingkungan yang tinggi $\left(25^{\circ} \mathrm{C}\right)$, kemudian kembali ke suhu yang rendah. Selain itu, minimnya bahan nitrogen cair dalam kontainer dapat menyebabkan suhu kontainer naik mencapai suhu $-150^{\circ} \mathrm{C}$ yang juga akan menyebabkan kerusakan pada spermatozoa. Perjalanan atau pengangkutan, misal dari BIB, SBIP baik Provinsi atau Kabupaten/Kota, sampai dengan pos inseminasi buatan, di bawah kondisi-kondisi yang buruk seperti kepanasan atau kedinginan yang berlebihan, dan kelemahan fisik dapat menurunkan kualitas semen dan fertilitas dari materi genetik jantan.

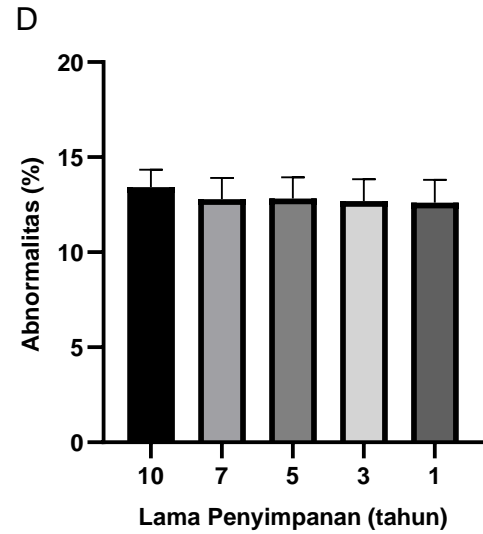

Gambar 4. Persentase abnormalitas spermatozoa semen beku.

Hasil pengujian statistik menunjukkan bahwa lama penyimpanan yang berbeda tidak berpengaruh nyata $(\mathrm{P}>0,05)$ terhadap abnormalitas spermatozoa Sapi Bali (Gambar 4). Rata-rata sebanyak $12,87 \pm 1,09 \%$ spermatozoa Sapi Bali teridentifikasi mengalami abnormalitas morfologi. Hasil tersebut menunjukkan bahwa semen beku Sapi Bali tahun penyimpanan di bawah 10 tahun masih dapat digunakan untuk inseminasi buatan. Setiap spermatozoa yang abnormal tidak dapat membuahi sel telur, selama abnormalitas spermatozoa belum 
mencapai 20\% maka semen tersebut masih dapat dipakai untuk inseminasi (Riyadhi et al., 2010).

Spermatozoa yang abnormal secara morfologi, baik abnormalitas primer atau sekunder, tidak dapat membuahi ovum. Demikian pula sesuai dengan standar dari Peraturan Menteri Pertanian Republik Indonesia No. 10/Permentan/PK.210/3/2016 tentang semen beku yang diproduksi dan diedarkan harus mempunyai abnormalitas $\leq 20 \%$. Jika abnormalitas spermatozoa melewati 30 sampai $35 \%$ maka menunjukan adanya infertilitas.

\section{Membran Plasma Utuh (MPU)}

Membran plasma yang utuh (MPU) merupakan hal yang mutlak harus dimiliki spermatozoa yang baik karena membran plasma memegang peranan yang sentral dalam mengatur seluruh proses biokimia yang terjadi di dalam sel. Membran plasma spermatozoa memiliki fosfolipid yang mengandung asam lemak tak jenuh sehingga sangat rentan terhadap serangan radikal bebas. Radikal bebas akan merangsang terjadinya reaksi autokatalik yang akan merusak membran plasma (Sukmawati et al., 2014). Fungsi keutuhan membran plasma spermatozoa adalah dalam metabolisme spermatozoa, reaksi akrosom, dan pengikat spermatozoa pada permukaan sel telur (Arsiwan et al., 2014).

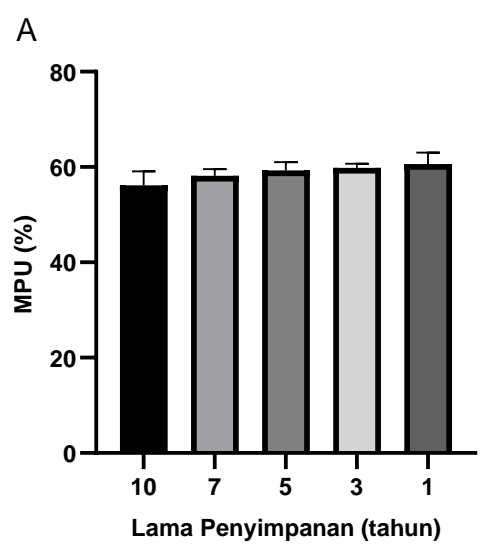

Gambar 5. Persentase membran plasma utuh (MPU) spermatozoa semen beku.

Pengaruh lama penyimpanan semen beku terhadap membran plasma utuh spermatozoa Sapi Bali dapat dilihat pada Gambar 5. Hasil pengujian statistik menunjukkan bahwa lama penyimpanan yang berbeda tidak berpengaruh nyata $(P>0,05)$ terhadap membran plasma utuh spermatozoa Sapi Bali. Rata-rata membran plasma utuh yaitu 58,83 $\pm 1,86 \%$. Hasil tersebut menunjukkan bahwa semen beku Sapi Bali dapat dipakai untuk inseminasi buatan sesuai dengan pendapat Anwar et al. (2015) bahwa dengan terjaganya membran plasma maka proses metabolisme spermatozoa juga tetap berlangsung dengan baik, yang berpengaruh positif terhadap motilitas spermatozoa selama penyimpanan berlangsung. Hal ini menunjukan bahwa keutuhan membran plasma menentukan hidup dan matinya spermatozoa, sehingga nilai persentase membran plasma utuh seharusnya tidak jauh berbeda dari nilai persentase spermatozoa hidup (Rizal et al., 2003).

Membran plasma berfungsi untuk memelihara integritas membran dan membentuk permukaan yang dinamis antar sel serta sebagai pelindung terhadap lingkungan ekstrim. Kerusakan membran pada bagian kepala menyebabkan enzim yang berfungsi untuk fertilisasi keluar dan spermatozoa kehilangan fertilitasnya serta kerusakan spermatozoa pada bagian ekor akan menyebabkan keluarnya enzim aspartat aminotransferase. Enzim aspartat aminotransferase yang berfungsi untuk merombak Adenosina Trifosfat (ATP) menjadi Adenosina Difosfat (ADP) dan Adenosina Monofosfat (AMP) akibatnya spermatozoa akan kehilangan kemampuan untuk bergerak (Priyanto, 2014).

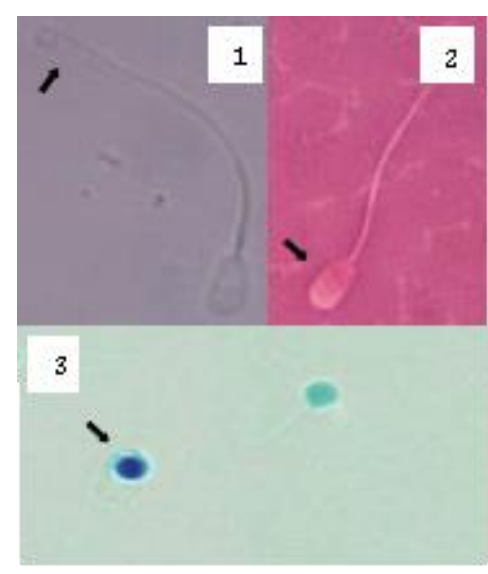

Gambar 6. Spermatozoa dengan membran plasma utuh (MPU) pada cairan Hypoosmotic Swelling Test (HOSTest), perbesaran 400x. 
Ekor spermatozoa terlihat melingkar (Gambar 6.1); spermatozoa dengan pewarnaan eosin-nigrosin menunjukan lapisan selubung pembungkus akrosom (Garmbar 6.2); dan spermatozoa berwarna biru tebal dengan pewarnaan toluidine blue menunjukan keutuhan DNA dan berwarna biru tipis sebagai indikasi kerusakan DNA (Gambar 6.3).

Pengukuran membran plasma utuh dengan metode hypoosmotic swelling test (HOSTest) digunakan untuk mengevaluasi fungsional dari integritas membran plasma. Integritas membran adalah suatu keadaan yang menunjukkan mekanisme fungsi fisiologi membran yang terjaga sebagai kontrol terhadap transport ion, sehingga cairan di luar sel tidak dapat masuk ke dalam sel. Menurut Sukmawati et al. (2014) jika membran plasma rusak maka proses metabolisme terganggu, sintesis ATP tidak berjalan dengan normal dan berakibat fatal yaitu menurunnya motilitas maupun daya tahan hidup spermatozoa. Kerusakan membran plasma dipengaruhi oleh beberapa faktor, seperti: 1) ketersediaan nutrisi bagi spermatozoa; 2) lingkungan yang tidak sesuai; 3) proses pengenceran dan pendinginan yang kurang tepat; 4) kualitas semen yang rendah dengan ditemukannya banyak spermatozoa yang abnormal; dan 5) terjadi kerusakankerusakan sel (Triwulanningsih et al., 2003).

\section{Tudung Akrosom Utuh (TAU)}

Keberhasilan inseminasi buatan harus diiringi dengan kualitas spermatozoa yang baik, kualitas yang baik tidak hanya dilihat pada motilitas progresif spermatozoa tetapi juga dilihat keutuhan tudung akrosom spermatozoa (Anwar et al., 2015). Tudung akrosom utuh merupakan lapisan yang menutupi nukleus, di dalamnya terdapat kumpulan enzim yang berfungsi membantu inti memasuki sitoplasma sel telur pada saat fertilisasi dengan merusak lapisan pembungkus sel telur melalui reaksi akrosom (Sugiarti et al., 2004).

Pengaruh lama penyimpanan semen beku terhadap tudung akrosom utuh spermatozoa Sapi Bali dapat dilihat pada Gambar 7. Hasil pengujian statistik menunjukkan bahwa lama penyimpanan yang berbeda tidak berpengaruh nyata $(\mathrm{P}>0,05)$ terhadap tudung akrosom utuh spermatozoa
Sapi Bali. Rata-rata kualitas tudung akrosom utuh spermatozoa Sapi Bali 75,48 $\pm 1,61 \%$. Hasil tersebut menunjukkan bahwa semen Sapi Bali pada lama penyimpanan di bawah 10 tahun di pos inseminasi buatan memenuhi syarat digunakannya untuk inseminasi buatan, sesuai dengan pendapat Anwar et al. (2015) yaitu keutuhan membran plasma spermatozoa dapat memperpanjang masa motilitas spermatozoa dan kecil kemungkinan kerusakan tudung akrosom spermatozoa. Keutuhan akrosom merupakan salah satu keberhasilan proses fertilisasi. Akrosom mengandung enzim-enzim yang dibutuhkan saat fertilisasi yang berfungsi untuk melisiskan lapisan pelindung oosit (Sugiarti et al., 2004).

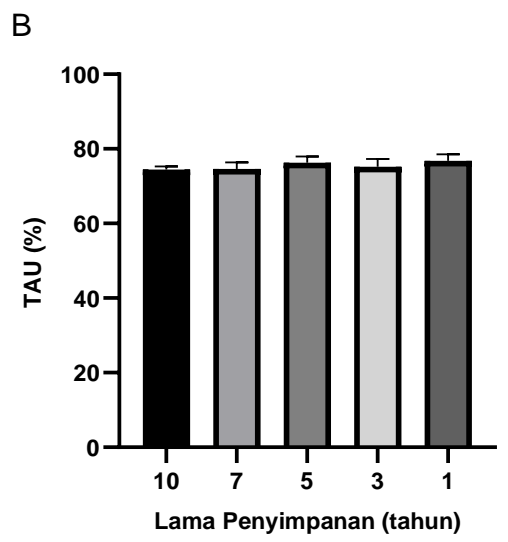

Gambar 7. Persentase tudung akrosom utuh (TAU) spermatozoa hidup.

Keutuhan tudung akrosom (TAU) merupakan salah satu parameter uji yang dilakukan pada semen beku. Persentase tudung akrosom utuh menurun seiring dengan bertambahnya waktu penyimpanan (Triwulanningsih et al., 2003). Kepala spermatozoa dibagi menjadi dua daerah, yaitu akrosom anterior yang dibungkus oleh tudung akrosom dan post akrosomal posterior. Tudung akrosom mengandung akrosin, hyaluronidase, dan enzim-enzim hidrolitik lainnya yang terlibat pada proses fertilisasi (Arifiantini et al., 2006). Kerusakan tudung akrosom spermatozoa diakibatkan karena proses penanganan dan pembekuan semen. Kristal-kristal es akibat dehidrasi sel yang berlebihan dapat menyebabkan kerusakan pada tudung akrosom spermatozoa (Samsudewa et al., 2007).

Menurut Ichwandi (2004) tudung akrosom merupakan suatu selubung yang 
terdapat pada bagian kepala spermatozoa yang berfungsi untuk melindungi keluarnya materi genetik dan enzim hyaluronidase. Enzim hyaluronidase mempunyai peranan penting untuk melisiskan zona pelusida pada sel telur yang berfungsi pada saat fertilisasi. Tudung akrosom perlu tetap utuh sebelum semen diinseminasikan agar enzim-enzim seperti hyaluronidase, akrosin, dan sebagainya yang terdapat di dalamnya dapat terbawa dan baru dilepaskan di dalam organ reproduksi betina.

\section{Kerusakan DNA Spermatozoa}

Kerusakan kromatin deoxyribose nucleic acid (DNA) spermatozoa merupakan faktor penting penyebab terjadinya infertilitas (Prabowo et al., 2016). Pada area kepala spermatozoa terdapat inti yang mengandung DNA yang merupakan komponen penting dalam proses fertilisasi. Semua informasi genetik yang akan diwariskan dari satu generasi ke generasi berikutnya terdapat pada untaian DNA di dalam inti spermatozoa (Saili et al., 2006). Gamet dapat bertahan pada suhu $-196^{\circ} \mathrm{C}$ untuk waktu yang tidak terbatas, meskipun dapat menyebabkan akumulasi kerusakan DNA yang tidak bisa diperbaiki oleh enzim (Sunarma et al., 2010). Pemeriksaan kerusakan DNA spermatozoa merupakan parameter penting dalam diagnosis fertilitas pejantan termasuk spermatozoa yang berasal dari semen beku (Erenpreisa et al., 2003).

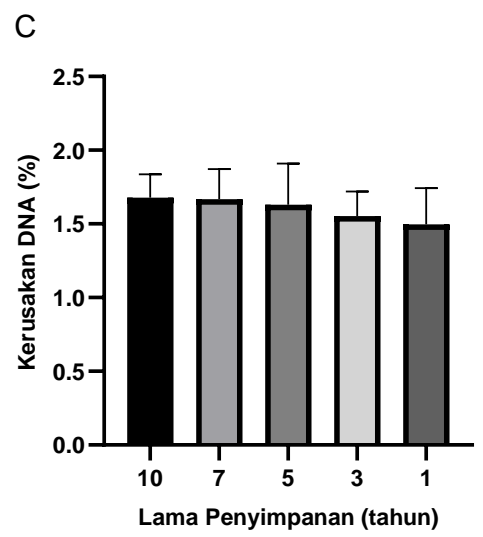

Gambar 7. Persentase kerusakan DNA spermatozoa pada semen beku.

Persentase kerusakan DNA spermatozoa Sapi Bali untuk semen beku yang disimpan sampai dengan 10 tahun pada setiap pos inseminasi buatan dapat dilihat pada
Gambar 7. Hasil pengujian statistik menunjukkan bahwa lama penyimpanan yang berbeda tidak berpengaruh nyata $(\mathrm{P}>0,05)$ terhadap DNA spermatozoa Sapi Bali. Kerusakan DNA spermatozoa Sapi Bali menunjukkan hasil rata-rata $1,60 \pm 0,21 \%$. Hasil tersebut berarti bahwa semen Sapi Bali memenuhi syarat untuk digunakan inseminasi buatan karena DNA spermatozoa terletak pada bagian dalam dari spermatozoa, posisinya terlindung oleh membran plasma dan akrosom. Hal ini sesuai dengan pendapat Priyanto (2014) yaitu kerusakan atau penurunan DNA terjadi apabila telah terjadi kerusakan pada membran plasma dan tudung akrosom yang mempengaruhi integritas DNA spermatozoa. Kualitas kromatin dalam inti sel sangat menentukan status DNA yang terikat erat pada protamin yang berfungsi sebagai pelindung bagi DNA inti (Saili et al., 2006). Proses thawing menjadi salah satu titik kritis kerusakan DNA spermatozoa. Saat thawing, spermatozoa mengalami perubahan suhu yang ekstrim menyebabkan kerusakan sel, menurunkan motilitas, viabilitas, keutuhan membran plasma, dan merusak DNA spermatozoa.

\section{KESIMPULAN}

Lama penyimpanan semen beku yang disimpan selama satu sampai sepuluh tahun pada nitrogen cair di pos inseminasi buatan Kota Samarinda, Kalimatan Timur masih layak digunakan untuk inseminasi buatan berdasarkan kualitas motilitas, viabilitas, velositas, abnormalitas, membran plasma utuh, tudung akrosom utuh, dan kerusakan DNA spermatozoa.

\section{DAFTAR PUSTAKA}

Anwar, P., Y.S. Ondho, dan D. Samsudewa. 2015. Kualitas membran plasma utuh dan tudung akrosom utuh spermatozoa sapi Bali dipreservasi suhu $5^{\circ} \mathrm{C}$ dalam pengencer ekstrak air tebu dengan penambahan kuning telur. Agromedia. 33(1): 53.63.

Arifiantini, I.T. Wresdiyati, dan E. F. Retnani. 2006. Morfologi spermatozoa sapi Bali (Bos sondaicus) menggunakan pewarnaan "Williams". Jurnal 
Pengembangan Peternakan Tropis. 31(2): 105-110.

Arsiwan, S.T., L.O. Baa, dan S. Rahadi. 2014. Membran plasma utuh spermatozoa epididimis kambing peranakan ettawa dalam natrium klorida dengan konsentrasi berbeda. JITRO. 1(1): 79-87.

Davila, S.G., J.L. Campo, M.G. Gil, C. Castano, and J. Santiago-Moreno. 2015. Effect of the presence of hens on roosters sperm variables. Poultry Science. 94(7): 16451649.

Erenpreisa J., T. Freivalds, M. Slaidina, J. Erenpreiss, R. Krampe, J. Butikova, A. Ivanov, and D. Pjanova. 2003. 'Toluidine blue test for sperm DNA integrity and elaboration of image cytometry algorithm. Cytometry Part A: The Journal of the International Society for Analytical Cytology. 52(1): 19-27.

Fauzan, M., M. Hartono, dan P.E. Santosa. 2014. Pengaruh suhu dan lama thawing di dataran rendah terhadap kualitas semen beku sapi Brahman. Jurnal Ilmiah Peternakan Terpadu. 2(3):1-7.

Feradis. M.P. 2010. Bioteknologi Reproduksi pada Ternak. Alfabeta. Bandung.

Ichwandi. I. 2004. Performans Motilitas, Tudung Akrosom Utuh dan Velositas Spermatozoa Tanpa dan dengan Metode 'Swim Up' Pasca Thawing pada Semen Beku Sapi Potong. Disertasi. Program Pascasarjana Universitas Diponegoro. Semarang.

Kusumawati, D.E., H. Leondro, dan A.T.N. Krisnaningsih, T. Susilawati, N. Isnaini, dan R. Widhad. 2016. Pengaruh suhu dan lama simpan semen segar terhadap motilitas dan abnormalitas spermatozoa kambing peranakan etawa (PE). Seminar Nasional Hasil Penelitian. 4(1): 199-208.

Permentan. 2016. Peraturan Menteri Pertanian Republik Indonesia tentang Penyediaan dan Peredaran Semen Beku Ternak Ruminansia. Nomor: 10/Permentan/PK.210/2/2016.

Kementerian Pertanian RI. Jakarta.

Prabowo T.A., R.I. Arifiantini, D. Sajuthi, dan U. Saefullah. 2016. Pengembangan metode identifikasi kerusakan DNA spermatozoa ternak. Jurnal Sain Veteriner. 32(2): 166-171.

Priyanto, L. 2014. Deteksi Kerusakan DNA
Spermatozoa Sapi Menggunakan Pewarnaan Toluidine Blue dan Kit Halomax ${ }^{\circledR}$ yang Dimodifikasi. Tesis. Sekolah Pascasarjana Institut Pertanian Bogor. Bogor.

Riyadhi M., R.I. Arifiantini, dan B. Purwantara. 2010. Kajian morfologi spermatozoa sapi simmental di beberapa Balai Inseminasi buatan di Indonesia. Hemera Zoa: Majalah Ilmu Kehewanan Indonesia. 1(2): 1-7.

Rizal M., M.R. Toelihere, T.L. Yusuf, B. Purwantara, dan P. Situmorang. 2003. Kualitas semen beku domba Garut dalam berbagai konsentrasi gliserol, Jurnal Ilmu Ternak dan Veteriner. 7(3): 194-199.

Saili, T., W.E. Prasetyaningtyas, M.A. Setiadi, S. Agungpriyono, dan A. Boediono. 2006. Status DNA spermatozoa domba setelah proses pengeringbekuan. Jurnal Ilmu Ternak dan Veteriner. 11(3): 215-221.

Samsudewa, D., M.I.S. Wuwuh, dan Y.S. Ondho. 2007. Pengaruh jumlah spermatozoa per inseminasi terhadap kualitas semen beku kambing peranakan Etawa. Seminar Nasional Teknologi Peternakan dan Veteriner. 462-468.

Situmorang, P., E. Triwulanningsih, A. Lubis, T. Sugiarti, dan W. Caroline. 2000. Optimalisasi penggunaan chilling semen untuk meningkatkan persentase kebuntingan sapi perah. Laporan Penelitian Balai Penelitian Ternak. Ciawi.

Standar Nasional Indoenesia (SNI). 2008 Semen Beku Sapi. Badan Standardisasi Nasional. Jakarta.

Sugiarti T., E. Triwulanningsih, P. Situmorang, R.G. Sianturi, dan D.A. Kusumaningrum. 2004. Penggunaan katalase dalam produksi semen dingin sapi. Seminar Nasional Teknologi Peternakan dan Veteriner. 215-220.

Sukmawati, E., R.I. Arifiantini, dan B. Purwantara. 2014. Daya tahan spermatozoa terhadap proses pembekuan pada berbagai jenis sapi pejantan unggul. Jurnal Ilmu Ternak dan Veteriner. 19(3): 168-175.

Sunarma, A., D.W. Budihastuti, dan Y. Sistina. 2010. Penggunaan ekstender madu yang dikombinasi dengan krioprotektan berbeda pada pengawetan sperma ikan 
Nilem (Indonesia Sharkminnow, Osteochilus hasseltii Valenciennes, 1842). Omni-Akuatika. 9(11): 51-55.

Syauqy, A. 2014. Evaluasi kromatin sperma sebagai indikator kualitas sperma. Jambi Medical Journal. 2(1): 87-97.

Toelihere, M.R. 1993. Inseminasi Buatan pada Ternak. Angkasa. Bandung,

Triwulanningsih E., P. Situmorang, T. Sugiarti, R.G. Sianturi, dan D.A. Kusumaningrum. 2003. Pengaruh penambahan glutathione pada medium pengencer sperma terhadap kualitas semen cair (chilled semen). Jurnal Ilmu Ternak dan Veteriner. 8(2): 91-97. 